\title{
TERMINATION OF COLLECTIVE DEFENSE TRETIES - PROCEDURES, CONSEQUENCES AND MODERN STATE PRACTICE
}

\author{
Victor SERAFIMOV \\ "Neofit Rilski”" South-west University, Blagoevgrad, Bulgaria \\ Victor.serafimov@gmail.com
}

\begin{abstract}
State practice has showed that geopolitical interests of nations are usually engaged either through diplomatic or military means. The mutual desire to avoid armed conflicts led to concluding multiple multilateral and bilateral international security and defence treaties. This process formed the basis of two major concepts -the Collective security and the collective defense. Both of them require a solid international legal basis, namely - a treaty that settles all forms of interpretations, disputes and actions. Since these treaties define international relations for a certain period, their eventual termination would have a major impact on the relations between different nations as seen numerously in the past decades. The contemporary world has completely different challenges to ensure collective security in the framework of international organizations. Currently major military actors are guarding the national sovereignty and aerospace borders of smaller states, thus making air policing a real diplomatic issue that should face an international legal framework. The institutional interaction between NATO and the EU as international organizations could lead to complete integration in terms of defense of the EU Member states in the near future. These issues could and should be met with the means of the main sources of the Law of treaties.
\end{abstract}

\section{Keywords: international treaties, termination procedure, collective defense}

\section{Introduction}

The international community has gradually accepted that the geopolitical interests of nations and states can be pursued through two main courses. The first one is by leading aggressive wars with other states [1]. From a historical point of view, this was the first one used by states. The devastating consequences of the twentieth century world wars, combined with the modernized weapons for mass destruction pressed the international community to develop an alternative method [2]. The second one is through diplomatic means. Even though this is a rather traditional approach, the historical failures of diplomacy pressed for an evolved diplomatic way of settling disputes between states on one hand and pursuing strategic geopolitical interests of countries on the other [3]. In that sense, collective security and collective defense systems emerged and gradually evolved [4]. These systems depended solely on the international treaties that formed them and the undeniable presumption that the treaties will be followed [5]. In that sense, the issues related to the binding force of international treaties, and for their application are of crucial importance for understanding modern international relations. Thus, the matter that will be explored in the present article is a cross-section between international relations, pure classical international law and the law of international treaties. The later is the 
instrument that regulates the forms of interpretation, validity and application of the concluded treaties.

\section{Collective Security vs. Collective defense treaties.}

The international community developed the two systems in a rather prolonged period of time. Even though the two have a number of common elements, they differ in some of their crucial and most defying points.

The collective security is a regional or global security system, which accepts that the security of one of the state actors is a concern of the whole systems, thus the system as a whole commits to collective response to threats and breaches of the peace [6]. It should be noted that this is one of the most promising systems of guaranteeing the global peace in the modern world. The concept, however, emerged as early as the XVII century and was reflected in the 1648 Peace of Westphalia [7]. The concept was then developed by Immanuel Kant in his works, including and foremost the Perpetual Peace: A philosophical sketch [8]. After WWI, the international community concluded that a new system for ensuring that no further global wars would emerge is needed. This led to the emergence of the League of Nations - a universal international organization that would seek to guaranteeing the international peace. The idea of a international body in which different nations could settle their disagreements has been discussed periodically since antiquity. The League was created as a result of the 1919 Paris Peace Conference and was the first organisation of sovereign states designed to be universal and devoted to the settlement of disputes and the prevention of war [9]. The League was in principle allowed to use military force, but the organization was deprived of a standing army of its own. This would mean that if a state, violated the rules of the organization and simply chose to ignore it, there was nothing the League could do [10]. Although the French delegation at the Paris Peace Conference insisted for the creation of an international army under control of the League of Nations, the idea received no serious support.

The United States, frightened by the possibility of American soldiers being summoned to fight on foreign soil by an organization refused to ratify the Treaty of Versailles. Thus, the United States did not become a member of the league, nor was the newly founded Russian socialist state a member. This, combined with the ineffective actions of the organization lead to its failure.

After World War II, the idea of collective security regained popularity. The international community had, however, learned from its previous mistakes. Thus, the United Nations was found as an international organization with a number of priorities, among which was to preserve international peace. Unlike the League, the United nations has universal membership. Namely, the UN is a universal international organization that forbids war as a means of the international policy of the states. The rule of peaceful solution of disputes and for collective actions in cases of jeopardy of international peace and security predominates. By this moment, the role of the United Nations in the process of ensuring that the principle of collective security is followed without any fails.

It should be noted, that the necessary conditions for collective security are quite demanding. First, all states must accept the status quo sufficiently to renounce the use of force for any purpose other than defense of their own territory. Second, all states must agree on a clear definition of aggression so that paralysis can be avoided if cases arise. Third, all states, and especially the global powers, must be willing to commit their own armed forces and/or funds to prevent aggression even if it is remote from, or opposed to, their immediate interests. Fourth, all states must 
actively prevent any breaches of sanctions that might assist the declared outlaw [11]. The collective defense system on the other hand is an arrangement, usually formalized by a treaty and organization. The system requires that the member states commit that should another member state be attacked by a state outside the organization, they would provide support in defense [12]. NATO is one of the best known collective defense organizations. Article 5 of the Treaty calls on member states to assist another member if attacked. This provision was invoked after the 2001 attacks on the United States, after which NATO members provided assistance to the US War on Terror in Afghanistan. It should be noted, that collective defense has its roots in multiparty alliances and entails benefits as well as risks. On the other hand, by combining and pooling resources, it can reduce any single state's cost of fully providing security.

This instrument has been applied in a number of cases in the $20^{\text {th }}$ century. The Cold war of the second half of the century was efficiently led by two political centers, each of which formed a collective defense system - NATO and the Warsaw pact. The Warsaw pact was based on the Treaty of Friendship, Cooperation and Mutual Assistance [13] that was terminated in 1991.

Another example of a collective defense system was the Western European Union that was formed with the 1948 Treaty of Brussels [14] that was consequently terminated in 2010 as a result of the provisions of the 2009 Lisbon Treaty [15].

Both of the described systems have been used on a global scale in order to preserve the global peace. In every case, the used mechanism was legally based on an international treaty that was to be followed by the relevant member states. The entry into force, the interpretations of the relevant provisions and the consequences of the breaches of these treaties were regulated by the general Law of international treaties. The practice of the international community has proved that the termination of such treaties is always an extremely delicate matter in international relations, thus making the international legal issues quite complicated [15].

\section{Termination of collective defense treaties - a case study of the procedures and consequences.}

The termination procedure of collective defense treaties follows the procedural rules, set in the general international law and the 1969 Vienna convention on the law of treaties [16]. As prescribed by Article 54 of the Convention, a treaty is to be terminated either in conformity with its provisions, or when there is consent between the parties or in conformity with the provisions of Section 3 of Part V of the Convention.

Article 11 of the Warsaw pact prescribes a certain period of time in which the treaty would be in force and in the same time includes a prolongation clause. The prolongation would apply to states that have not given notices of termination. The same provision prescribes that the treaty would be terminated in cases of novation when the parties conclude new collective defense treaty [17]. These treaty provisions provide that in these cases the collective defense system established by the Warsaw pact would be terminated. Since the parties to the Pact are also parties to the 1969 Vienna convention on the law of treaties, the later would be applicable law. In that sense, the treaty could be terminated or denunciated by any of the parties should the any of the hypothesis of the provisions of Articles 55-64 be executed.

The treaty was terminated effectively as of December 1991 as a result of the unilateral denunciation of a number of states [18]. The first one to withdraw was East Germany in 1990 and during a meeting of the foreign ministers of the member states, the Pact was declared to be terminated. After completing the necessary denunciation procedures, the Treaty was terminated by the end of 1991. The member 
states, including - Romania and Bulgaria denunciated the treaty following the procedure, set up in the provision of Article 56 of the 1969 Vienna convention on the law of treaties. It could be argued whether the prerequisites of this provision have been dully met but the practice showed that no state was interested in maintaining the treaty and/or seeking remedies for a potentially unlawful termination of this collective defense treaty [19].

Similarly to the Warsaw Pact, the 1948 Brussels treaty that formed the Western European Union includes an explicit provision under Article $\mathrm{X}$ that prescribes that after 50 years in effect, the Treaty could be unilaterally denunciated by a member state with a formal notice of one year [20]. Again, since the member states of the Western European Union are parties to the 1969 Vienna convention on the law of treaties, the procedural rules and the grounds for termination set in Section 3 of Part V of the Convention are to be applied. This collective defense system was effectively in force from 1948 by 2011 . The 1948 Brussels treaty was terminated by consent of the parties, which gradually transferred the functions of the organization to the European Union. The 2009 Lisbon treaty included a solidarity clause that was similar, yet not identical to the mutual defense clause of the Western European Union [21]. In that sense, the organization was no longer needed, thus the 1948 Brussels Treaty could be terminated. This was decided by representatives of the member states in 2010 and was completed in 2011.

In both cases, the collective defense treaties were terminated on grounds that were not explicitly included in the treaties but were rather a part of the Law of International treaties. In the first case - the Warsaw pact was terminated by unilateral denunciation procedures by all of the member states, which led to termination of the whole treaty. In the second case - the Brussels treaty was terminated by consent of all of the parties. The decision was political and was derived from the complete integration of the organization in the fully operational European Union.

\section{Collective defense treaties - modern state practice}

The modern state practice in the field of collective defense treaty is rather complicated. After the termination of the Warsaw pact, both Romania and Bulgaria joined NATO in 2004. In that sense, both states joined this collective defense system after the exiting the Warsaw pact. In the NATO context, both states have been actively involved in a number of activities related to the organization. In that sense, Romania took part in the Air policing mission in Baltics. Air policing is a rather hot topic in this sphere. The idea of collective defense organization could basically be explained in two main ways guaranteeing the security of the member states and combining the defense resources of the members in order to achieve better results with the same funds. In that sense, air policing allows smaller state actors to use the air forces of other member states to guard their airspace. This, being rather costeffective brings a number of questions and issues. The missions are usually undertaken after a decision of an international body that includes the main elements of this transaction [23]. It should be, however, noted that there is no international legal instrument that settles the issues related to air policing in general. Even though they are formed ad hoc for every mission, an international treaty that settles all of the relevant issues should be adopted. This would ensure that all of the state actors would be acquainted with the procedure and all of its issues. In that sense, since this trend could only be amplified, the matter should find a general regulation.

The termination of the 1948 Brussels Treaty and the Western European Union only brings forward the general question of complete military integration of the 
European Union member states. The issue, despite being extremely delicate has been brought forward numerously in the EU institutions. The Common Security and Defense Policy is a tool that ensures that this could and probably would be completed. The Policy currently includes the option to use certain military forces in certain cases. The potential transfer of additional rights to this body would complete the process. Again, this would be done in terms of a joint command force, that would led to better cooperation and better use of resources [23].

\section{Conclusions}

After defining both collective security and collective defense, the present study explored the international practice in terminating collective defense treaties and the modern state practice and challenges in front of the international community as a whole. The rising issues are related to two main conclusions. On one hand, the military integration of EU member states is a probable next step in the integration process in the Union. It is expected after dissolving the Western European Union. This could only be completed with a decision of the EU itself and with treaty to settle this process and the arising issues. The second conclusion is related to the cooperation in different spheres of defense between member states of collective defense systems. Air policing is currently a major topic in this sphere and the lack of regulation could potentially lead to institutional clashes. In order to avoid them, a new general treaty could be adopted to regulate this matter. An alternative measure would be adopting detailed rules by a collective defense organization but for obvious reasons, they would lack universal character. This, despite being a major disadvantage of the concept could be a first step in this process.

\section{References}

[1] Mösslang, Markus, and Torsten Riotte. The Diplomats' World A Cultural History of Diplomacy, 1815-1914. Oxford: Oxford University Press, 2008.

[2] Black, Jeremy. A History of Diplomacy. A History of Diplomacy. London: Reaktion, 2011.

[3] Kissinger, Henry. Diplomacy. 1994.

[4] Lynn-Jones, Sean M., and Steven E. Miller. Global Dangers: Changing Dimensions of International Security. Cambridge, Mass: MIT Press, 1995.

[5] Schachter, Oscar. International Law in Theory and Practice. Dordrecht, The Netherlands: M. Nijhoff Publishers, 1991.

[6] McNair, Arnold Duncan McNair. Collective Security. Cambridge [England]: University Press, 1936.

[7] Tsagourias, Nikolaos K., and Nigel D. White. Collective Security: Theory, Law and Practice. 2016.

[8] Kant, Immanuel. Perpetual Peace. New York: Liberal Arts Press, 1957.

[9] Gall, Timothy L., and Derek M. Gleason. Worldmark Encyclopedia of the Nations. Detroit: Gale Cengage Learning, 2012

[10] Williams Bruce Stockton, State security and the League of Nations. Baltimore: The Johns Hopkins Press. 1927, p. 346

[11] Aleksovski, St., O. Bakreski, B. Avramovska. Collective security - the Role of International Organizations - Implications in International Security Order. Mediterranean Journal of Social Sciences, Vol. 5 No. 27, 2007

[12] Claude Jr. Inis L, "Collective Security as an Approach to Peace", in Classic Readings and Contemporary Debates in International Relations, ed. Donald M, Donald M. Goldstein, Phil Williams, \& Jay M. Shafritz, (Belmont, 2006), pp. 289-302 
[13] Pappas, Aris, and Mark Kramer. Warsaw Pact, 1955-1991: Treaty of Friendship, Cooperation and Mutual Assistance: Soviet-East European Military Relations in Historical Perspective: Sources and Reassessments. Washington, DC: Central Intelligence Agency, 2009

[14] Western European Union. Brussels Treaty - Texts of the Treaty, the Protocols and Other Documents Concerning Western European Union

[15] Ferrell, Robert H. American Diplomacy: The Twentieth Century. 1988.

[16] United Nations, Vienna Convention on the Law of Treaties, 23 May 1969, United Nations, Treaty Series, vol. 1155, p. 331

[17] Treaty of friendship, co-operation and mutual assistance between the People's Republic of Albania, the People's Republic of Bulgaria, the Hungarian's People's Republic, the German Democratic Republic, the Polish People's Republic, the Romanian People's Republic, the Union of Soviet Socialist Republics and the Czechoslovak Republic, United Nations Treaty Series, Vol. 219, p. 3

[18] https://treaties.un.org/pages/showDetails.aspx?objid=08000002801488a3

[19] Warsaw Pact: Alliance in Transition? [Place of publication not identified]: Palgrave Macmillan, 2014.

[20] Western European Union. Proceedings - Assembly of Western European Union. Actes officiels - Assemblée de l'Union de l'europe occidentale. Paris [etc.]: W.E.U., 1955.

[21] Craig, Paul P. The Lisbon Treaty: Law, Politics, and Treaty Reform. Oxford [etc.]: Oxford University Press, 2013.

[22] Murphy, John E. Air Policing. Biblioscholar, 2012.

[23] Vigulis, Ainars. Nato Air Policing: A Permanent Solution. Bibliogov, 2012. 